\title{
O papel de João Gonçalves da Costa na produção do espaço baiano entre os séculos XVIII e XIX: as origens do território de Vitória da Conquista
}

\author{
The role of João Gonçalves da Costa in the production of Bahian space - 18th and 19th \\ Centuries: the origins of the territory of Vitória da Conquista
}

\section{El papel de João Gonçalves da Costa en la producción del espacio bahiano - Siglos XVIII y XIX: los orígenes del territorio de Vitória da Conquista}

Altemar Amaral Rocha ${ }^{1}$ https://orcid.org/0000-0002-6278-052X

\footnotetext{
${ }^{1}$ Professor Adjunto do Departamento de Geografia e membro do Programa de Pós-Graduação em Geografia da UESB- Bahia Brasil email - Altemarrocha@gmail.com
}

\section{Resumo}

Este artigo baseia-se na análise dos processos de formação territorial da Bahia que configuram a produção do espaço no período Colonial Português na América entre os séculos XVIII e XIX, verificando a atuação de João Gonçalves da Costa nesse processo; em especial as origens do território de Vitória da Conquista pela invenção do Sertão da Ressaca no Centro Sul Baiano. Analisa as transformações socioespaciais ocorridas nas terras que hoje configuram a cidade e o município de Vitória da Conquista, bem como as demais cidades e municípios que compõe o território do Centro-Sul e Sul da Bahia, com o objetivo de compreender os processos territoriais que deram origem as nucleações urbanas que configuram as cidades desta região no século XXI.

Palavras-chave: Produção do Espaço. Território. Sertão.

\begin{abstract}
This article is based on the analysis of the processes of territorial formation in Bahia that configure the production of space in the Portuguese Colonial period in America between the eighteenth and nineteenth centuries, verifying the performance of João Gonçalves da Costa in this process; especially the origins of the territory of Vitória da Conquista for the invention of the Sertão da Ressaca in the Center South of Bahia. It analyzes the socio-spatial transformations that occurred in the lands that today make up the city and the municipality of Vitória da Conquista, as well as the other cities and municipalities that make up the territory of the Center -South and South of Bahia, in order to understand the territorial processes that originated the urban nucleations that shape the cities of this region in the 21 st century..
\end{abstract}

Keywords: Production of Space. Territory. Hinterland.

\section{Resumen}

Este artículo se basa en el análisis de los procesos de formación de Bahía territoriales que dan forma a la producción del espacio en el período colonial portuguesa en América entre los siglos XVIII y XIX, el control de la obra de João Gonçalves da Costa en este proceso; en especial los orígenes del territorio de Vitória da 
Conquista por la invención del Sertão da Ressaca en el Centro Sul Baiano. Se analiza las transformaciones socioespaciales ocurridas en las tierras que hoy configuran la ciudad y el municipio de Vitória da Conquista, así como las demás ciudades y municipios que componen el territorio del Centro-Sur y Sur de Bahía, con el objetivo de comprender los procesos territoriales que dieron origen las nucleaciones urbanas que configuran las ciudades de esta región en el siglo XXI.

Palabras clave: Producción del espacio. Territorio. Hinterland.

Recebido em: 29/10/2018

Aceito para publicação em: 21/12/2018

\section{Introdução}

A análise dos processos de formação territorial da Bahia, entre o período colonial e Império em especial o Centro Sul Baiano é uma questão primorosa para o desvendamento dos aspectos históricos que desencadearam uma série de transformações socioespaciais e, por consequência, consolidou o modo de vida das pessoas que compõe a sociedade atual, pois como afirma Lefebrve (2013, p. 76) "se há produção e processo produtivo do espaço, há história".

Assim, partindo da análise das transformações ocorridas nas terras que hoje configuram a cidade de Vitória da Conquista e demais cidades que compõe o território do Centro Sul e Sul da Bahia, pelo processo produtivo que se materializou no espaço do sertão baiano com o objetivo de compreender a origem da nucleação urbana que configuram as cidades desta região no seculo XXI.

Destaca-se a produção do espaço e as relações socioespaciais como fio condutor da pesquisa. Sobretudo aquelas relações socioespaciais ocorridas no século XVIII por todo o Centro-Sul e Sul da Bahia. Pois como afirma Neves (2012, p.15) "Os sertões da Bahia, até finais do século XVIII, eram pouco habitados".

No entanto, já havia uma série de ocupações e aldeamentos por todos os cantos do território baiano que naquela época limitava-se com a margem do Rio São Francisco e a ocupação se deu partindo de Salvador para Jacobina e, de Jacobina para os Sertões do Norte e do Sul e Centro Sul na divisa com Minas Gerais.

Foram realizadas várias incursões no território de Vitória da Conquista e dos demais municípios da região para detectar os traços que marcam os processos e transformações socioespaciais derivados da ocupação portugusa, sobretudo as ocupações inicadas por Jõao Gonçalves da Costa no Seculo XVIII, bem como um 
levantamento de dados sobre os primórdios da ocupação territorial que culminou no núcleo urbano ao qual passou a ser a atual cidade de Vitória da Conquista e as demais cidades. O resultado disso foi uma análise detalhada do processo de produção espacial elencando, os traços que marcam a configuração territorial do antigo Sertão da Ressaca atual território de Vitória da Conquista e dos demais municípios da região.

\section{João Gonçalves da Costa: entre a Europa e a América Portuguesa}

João Gonçalves da Costa nasceu por volta de 1731 na Província de Trás-osMontes, norte de Portugal e ao contrário do que muitos afirmam em pesquisas historiográficas, ele muito provavelmente não era preto-forro. Saiu de Portugal em 1747, com destino à Colônia Portuguesa na America do Sul, atual Brasil. Assim como seus parentes consanguíneos da família Gonçalves e Mathias João da Costa ambos vieram da mesma província de cidades como Montalegre e Chaves e se estabeleceram no Sertão da Bahia em Meados do Século XVIII. (mapa 1)

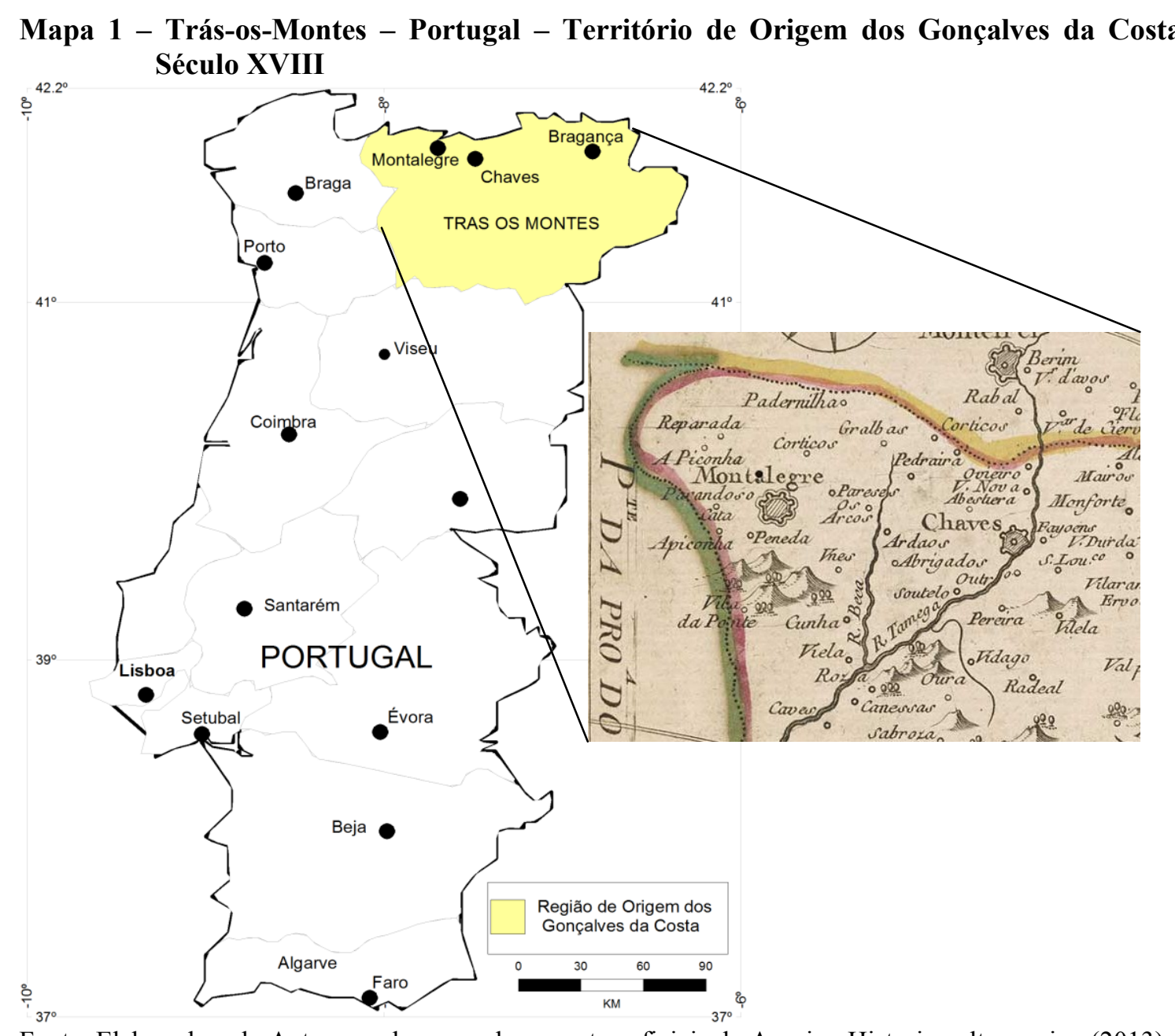

Fonte: Elaborado pelo Autor com base em documentos oficiais do Arquivo Historico ultramarino (2013) 
A biografia de João Gonçalves da Costa é bastante controversa tanto pelas divergências que o próprio capitão provocou enquanto estava vivo quanto pela escassa documentação existente sobre os relatos de suas atividades enquanto bandeirante pelo Sertão da Ressaca e por todo o território do Centro Sul da Bahia.

Sobre suas ações no território baiano, estas podem ser analisadas com auxílio de alguns fragmentos de documentos oficiais da Coroa Portuguesa e relatos originais de alguns pesquisadores da época. Um dos primeiros relatos da presença de João Gonçalves da Costa na Bahia oitocentista foi do Governador da Bahia Manuel da Cunha Menezes que em 1779 houve falar pela primeira vez das feitorias do João Gonçalves.

Menezes descreve:

Lembrei-me de abrir uma estrada, que em linha reta cortasse pelo meio da Capitania até sair na estrada geral do Rio São Francisco, para cujo efeito, tendo noticia de um homem, que com a sua família vivia nas cabeceiras da citada Capitania, no sertão da ressaca, chamado João Gonçalves, o qual obrigando-se não sei o motivo para aquele deserto por dilatado tempo, não logrou ver o fruto do seu trabalho, ...mas como lhe foi agregando alguns casais de índios domésticos e teve com que comprar alguns escravos, hoje tem no rancho(arraial da Conquista) mais de 60 pessoas e rodeados das fazendas de gado, fornece gado para Nazaré. Fiz vir o homem a minha presença, propuslhe as conveniências que se lhe seguiriam se houvesse um caminho mais curto e para umas povoações sem açougues e sem gados para a lavoura e transportes, e povoações para onde principiava a entrar com abundancia dinheiro da Fazenda Real e de Particulares, para madeira de construção de navios e de outras embarcações menores: não lhe desagradou a proposta, prometendo-me entregar a estrada em 3 anos. No mês de outubro passado, se concluiu a estrada parando o honrado homem com sua gente no sitio chamado Funil, sitio do próprio, para dele destacarem as estradas para as demais vilas entre Ilhéus, Camamu, Jaguaribe e Salvador. (grifos meus). (MENEZES, 1780, p. 478).

Esta foi a primeira documentação oficial sobre a existência do arraial da Conquista, bem como do Português João Gonçalves da Costa e sua gente. Como o próprio Governador afirma, nesse período, (1780) já existiam cerca de 60 pessoas morando no Arraial.

É possível verificar que a partir deste encontro com o então Governador em outubro de 1779 , e de seus relatos sobre sua trajetória no Sertão da Bahia, João Gonçalves da Costa, habilitou-se para receber o titulo de Capitão Mor da Conquista, titulo emitido pelo então governador Marquez de Valença (quadro 1). 


\section{Quadro 1- Documentos oficiais sobre João Gonçalves da Costa catalogados no Arquivo} Historico ultramarino-Lisboa-Portugal

Requerimento do Capitão mór João Gonçalves da Costa, no qual pede a justificação dos seus serviços.

CARTA patente pela qual o Governador Marquez de Valença nomeou João Gonçalves da Costa Capitão mór da Conquista do sertão da Ressaca.

Bahia, 31 de julho de 1781. Certidão. (Annea ao n. 21.725).

Portarias (7) dos Governadores D. Rodrigo José de Menezes e D. Fernando José de Portugal e de aratros, dirigidas ao Capitão mór João Gonçalves da Costa sobre a conquista do gentio e os serviços por elle prestados na submissão dos Indios Nongonhos.

V. datas. (Annexas ao n. 21.725).

$21.727-21.733$

Carta do Ouvidor da comarca dos Ilhéos Francisco Nunes da Costa para o Capitão mór Joâo Gonçalves da Costa, em que se refere á conquista do gentio e o elogia pelos seus relevantes serviços.

Bahia, 17 de fevereiro de 1785. (Annexa ao n. 21.725).

Atrestado do Brigadeiro José Clarque Lobo, sobre os valiosos serviços prestados pelo Capitão mór João Gonçalves da Costa na conquista do gentio barbaro.

Bahia, 8 de novembro de 1796. (Annexo ao n. 21.725).

21.735

Requerimento de João Gonçalves da Costa, no qual pede para juntar a certidão da sua carta patente, por ter a original em Lisboa para a sua confirmação regia.

(Annexo ao n. 21.725).

21.736

Fonte: Arquivo Histórico ultramarino - Biblioteca Nacional - Brasil (2013).

Neste momento entre (1779-1781), Joao Gonçalves passa a ser conhecido e reconhecido pelas autoridades da Coroa Portuguesa. Este fato pode ser percebido em documento oficial dos governadores interinos da Bahia à Corte em Lisboa do qual relatam:

A abertura de huma estrada de comunicação entre as vilas da comarca de Ilhéus com os sertões de suas cabeceiras. Para este grande e trabalhoso projecto se lhe apresentou João Gonçalves da Costa povoador do referido sertão da Ressaca homem natural de Chaves, com o valor e espírito dos antigos paulistas e sem a sua ambição; a elle destribuiu o Governador as ordens e elle foi o que teve a paciência e a Constancia de se metter pelas ásperas mattas, serras alagadiças, que pelo espaço de 80 ou mais legoas se interpõe entre as ditas villas da beira mar o referido sertão da Ressaca. Demarcou e abriu a estrada, que discorre a margem do Rio das Contas, donde a fez partir para as vilas da foz do mesmo rio, para a do Camamú e desta para todo o território das outras villas fazendo logo descer hum lote de gado, que foi o primeiro que aqueles moradores viram e também o primeiro que parte se destribuiu pelos lavradores e parte se talhou nos açouges públicos, o que nunca se tinha visto dês a descoberta e 
povoação daquela comarca. Neste tempo terminou o governo do Exmo. Manuel da Cunha Meneses e conhecendo o seu successor o Exmo. Marquez de Valença a importância deste projeto, a satisfação com que os povos receberam a primeira descida dos gados, a utilidade do commercio, da agricultura e da Fazenda Real continuou em expedir novas ordens a beneficio do aldeamento e conservação da mesma estrada, mandando outrosim situar huma nova povoação na beirada do Rio de Contas, para servir como repouso aos que commerciassem pela dita estrada e para melhor se aproveitarem de suas excellentes e ricas mattas, antes desconhecidas e inúteis. Condescendeu ao mesmo tempo com outro projeto do mencionado João Gonçalves da Costa, na reducção e conquista do gentio Nongoyo, que infesta o mesmo sertão da Ressaca. Encarregou- o desta empreza e o mandou municiar com 70 armas de fogo alguns barris de pólvora, para 50 indios dos civilizados à sua ordem, recomendando a execução e direção de hum e outro projeto ao Desembargador Francisco Nunes da Costa, que S. M. foi servido despachar para esta relação da Bahia, com exercício na dita Comarca dos Ilheus, o qual passou ao sertão do rio referido, situou a povoação e expediu a tropa da conquista ou bandeira, como vulgarmente se chama debaixo das ordens do mencionado João Gonçalves da Costa. Nos dois annos que se seguiram a estas ultimas ordens durante o governo do Exmo. Marquez de Valença mudou consideravelmente o estado daquela Comarca (Ilhéus). O referido João Gonçalves da Costa, já honrado com a patente de Capitão-Mór, participa presentemente dos progressos ou rezultas da conquista que foi encarregado, na carta que dirigiu ao dito desmbargador e que elle nos fez patente, acompanhando com a sua conta, que igualmente remettemos a V. Ex. para por ellas fazer conceito do valor e espírito deste honrado trasmontano, que pode concluir hum tão importante serviço, como reputamos, a redução de hum gentio dócil e laborioso, em que se descobre qualidades, que destinguem de todos os índios deste continente, tão indolentes como bárbaros, o gênio destes se conhece pelo seu modo de viver. (BOCARRO\&CASTANHEDA; CORREA; LOBO, 1783, p. 538). (grifos meus).

Destaca-se nessa narrativa, pelo menos três importantes provas sobre a origem a data da ascenção ao titulo de Capitão-Mor da Conquista o modo como se comportava João Gonçalves da Costa e os demais membros representantes da Coroa portuguesa nas terras da Bahia Colonia. Outra questão é o termo "trasmontano", que confirma categoricamente a origem de João Gonçalves da Costa, ou seja, nasceu na Região de Trás-os-Montes em Portugal e, muito provavelmente não era negro, porque nesse período, entre os séculos XVI e XVIII, os negros escravos ou negros forros que viviam em Portugal residiam entre Lisboa e Faro no Algave, sul de Portugal. Principal entrada de negros da África em Portugal.

Constata-se que, quando recebe a patente de Capitão-mor em 31 de julho de 1781, João Gonçalves da Costa sai do anonimato da população flutuante da Colônia Portuguesa aqui na América e entra definitivamente para o rall dos atores portugueses 
que atuaram na dizimação dos gentios (índios nativos da América) e na anexação, ocupação territorial e demarcação de terras na América Portuguesa, consolidando suas incursões pelo território baiano, ocupando terras pertencentes à Capitania de Ilhéus, terras que estavam em litígio jurídico entre Minas Gerais e Bahia.

\section{Do território indígena ao território do Sertão baiano os primórdios da produção do espaço no sertão da Bahia}

O território e sua configuração no processo de formação territorial decorrente da produção do espaço podem ser evidenciados pelas ações do estado, pelas forças produtivas e atores da formação socioespacial. Para Carlos (2011) a análise do processo de produção do espaço, é necessária a justaposição de vários níveis da realidade, bem como momentos diferenciados da reprodução geral da socieadade, por isso justifica-se a busca pelos primórdios da produção do espaço no Sertão da Bahia e em particular o território de Vitória da Conquista.

Para Santos (2008 p. 25) “A atual importância do território (para não falar de espaço) na realização da história" de um determinado lugar pode ser indicada pelo interesse crescente dos motivos pelos quais o cotidiano das pessoas é do jeito que é, ou seja, para o planejamento das políticas públicas e das ações econômicas.

Já o espaço, sobretudo o que contem as bases naturais da produção social, assume uma importância fundamental, na análise, pois, "a Natureza se transforma, em seu todo, numa forma produtiva" cada vez mais acelerada (PRESTIPINO, 1977, p. 181 apud SANTOS, 2008, p. 39). A natureza é sem dúvida um marco inicial para balizar a análise da configuração territorial no período do Brasil Colônia, já que a base econômica da sociedade moderna na Europa durante os seculos XVIII e XIX era a exploração dos recursos naturais e materia prima para as manufaturas em franca expansão nos países centrais da Europa.

É preciso ressaltar e confrontar aqui a ideia conceitual de território já que temos uma noção de território herdada da "Modernidade incompleta" do seu legado de conceitos puros, tantas vezes atravessando os séculos praticamente intocados. "É o uso do território, e não o território em si mesmo, de que faz dele objeto da análise social" (SANTOS, 2006, p. 15).

Ou, como afirma Silveira (2011), o território usado não é uma coisa inerte ou um palco onde a vida se dá. Ao contrário, é um quadro de vida, híbrido de materialidade e 
de vida social. Sinônimo de espaço geográfico pode ser definido como um conjunto indissociável, solidário e "contraditório, de sistemas de objetos e sistemas de ações" (SANTOS, 2004, p. 39). É o território propriamente dito mais as sucessivas obras humanas e os próprios homens hoje.

Nessa concepção entende-se que o movimento que se produz então, e que produz uma nova realidade social, não se baseia nem sobre a cidade (o urbano) considerada à parte, nem sobre o campo tomado isoladamente, mas sobre sua relação (dialética) no espaço, a partir de sua história (LEFEBVRE, 2013 p. 119).

Nesse sentido a produção do espaço no Centro Sul da Bahia a partir da criação do mundo imagético pelo surgimento do dito Sertão da Ressaca nos conduz a uma consolidação do território pelo uso e ocupação das terras num novo paradigma produtivo se antes os nativos gentios nogonhos viviam da caça e da pesca agora é introjetado no contexto sociocultural e socioespacial dessas tribos novos mecanismos produtivos seja pelo plantio do algodão, pelo cultivo do milho, feijão e hortaliças seja pela criação de gado na mata e nos campos extensivos do dito sertão da Ressaca.

Entre 1750 e 1780, foram várias incursões de João Gonçalves da Costa provavelmente junto com o Mestre de Campo João da Silva Guimarães que transitava entre Minas e Bahia com frequência.

Nesse mesmo período entre 1750 e 1807 o domínio de suas incursões foi no chamado Sertão da Bahia, dando origem ás primeiras povoações e aldeamentos no referido sertão entre o Rio Pardo e o Rio de Contas e entre o Rio Gavião e o Rio Catolé, incluindo-se ai neste contexto a implantação do arraial da Conquista no pé da Serra do Periperi, às margens do rio Verruga.

Com suas ocupações territoriais, João Gonçalves da Costa foi demarcando varias propriedades de terras, seguida pela abertura de estradas entre o litoral e o sertão e entre o Sertão e a Capital da Bahia, criou o que se convencionou de Sertão da Ressaca, nome amplamente difundido nos documentos oficiais da Coroa Portuguesa, mas para isso, foi preciso dizimar centenas de índios, principalmente índios da tribo Camacan ou como afirma os documentos oficiais da época gentios Nogonhos.

Antes disso João Gonçalves já havia fincado suas raízes com a abertura da estrada entre Conquista e Nazaré no Recôncavo Baiano, nesse trajeto, ele ocupou terras onde é o atual território de Planalto, terras no atual território de Poções, terras na atual Boa Nova, e as terras entre Boa Nova, Jequié e Jequiriçá. Seguindo o rio de Contas, ocupou terras até a barra do Funil onde foi construída uma base de fiscalização de 
contrabandos das mercadorias que iam em direção à Capital da Capitania de Ilhéus entre 1779 e 1807.

Nessa época Varias etnias Indigenas ainda predominavam em uma vasta abrangência territorial. Pelo menos quatro grupos e ou nações indígenas prevaleciam e guerreavam entre si e entre os Portugueses que por essas terras interiorizavam-se.

\section{Mapa 2 - Território das Etnias Indigenas que povoavam o Centro Sul da Bahia entre os} Séculos XVI a XIX

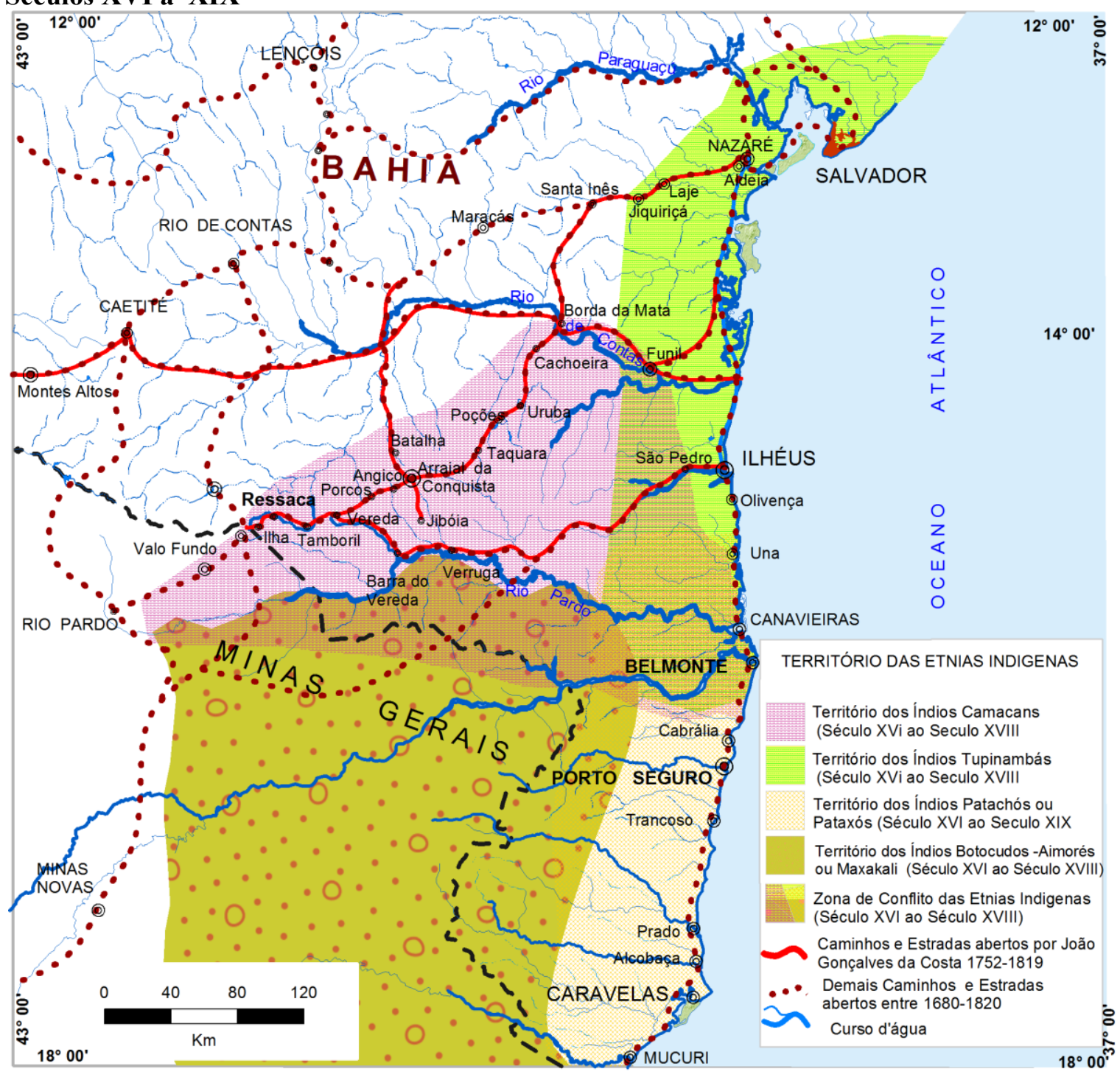

Fonte: Arquivo Historico ultramarino - Biblioteca Nacional - Brasil (2013). Livro Viagem ao Brasil de Maximiliano - 1817 (1940)

As principais tribos indígenas do território pré Colonial e pós Colonial denominado de Bahia eram: os Tupinambás que ocupavam a faixa litorânea entre Salvador e Ilhéus; os Pataxós ou patachós como eram chamados naquela época, que ocupavam as terras entre São Mateus no Espirito Santo e lhéus na Bahia, (mapa 1). 
Entre o litroal e Sertão da Bahia, habitavam os Camacans ou Mongoiós e Cutachos como eram chamados pelos Portugueses, e os Botocudos que povoavam as terras entre o Rio doce Minas Gerais e o Rio Pardo na Bahia.

Com sua patente de capitão em mãos, João Gonçalves da Costa, ganha não somente reconhecimento, mas a titularidade de suas terras que iam muito além das fronteiras da Bahia, (ROCHA, 2013). Assim, expandindo o território e aumentando suas propriedades, como foi relatado em sua memória sumária e compendiosa da conquista do Rio Pardo (1806-1807). Nela João Gonçalves narra a ocupação territorial ao sul do Rio Pardo entre os atuais municípios de Encruzilhada, Macarani e divisa Bahia/Minas Gerais na barra do rio do Salto.

Em outra narrativa, João Gonçalves aponta mais uma ocupação territorial na Barra do Rio Catolé, atual Itapetinga. Segundo Costa (1807 p. 7), seguindo sua trajetória pelo rio, "várias tribos de botocudos se avistavam fumegando nas florestas", após sua navegação pelo Rio Pardo entre a barra do Catolé até a foz, em Canavieiras, João Gonçalves da Costa, partiu pelo litoral até Ilhéus e, de lá negociou com o Governador Conde da Ponte, a abertura de uma estrada entre o litoral e sertão, a qual devido a sua idade avançada não teve condições de seguir na empreita.

A estrada foi iniciada em 1810, pelo brigadeiro Felisberto Caldeira Brant Pontes, aproveitando os trechos de estrada construídos pelo Capitão-mor João Gonçalves entre o Valo Fundo e a barra do Rio Catolé no Rio Pardo.

Sobre as ações, a origem e a idade de João Gonçalves da Costa o Príncipe Maximiliano descreve:

João Gonçalves da Costa... Um velho de 86 anos, ainda ativo e robusto; vencia em vivacidade muita gente moça. Reconhecia-se sem custo que, em idade menos avançada, devia ter sido dotado de grande vigor, coragem e ousadia. Recebeu-me da forma mais amigável possível, testemunhando a alegria de poder ver um europeu. A sua palestra era instrutiva e cheia de interesse para qualquer viajante. $\mathrm{Na}$ idade de 16 anos, seguia a sua vocação, que era a de conhecer terras distantes. Abandonou sua pátria, Portugal, e veio estabelecer-se no meio das montanhas selvagens do sertão da capitania da Bahia, onde se abria, às suas energias, um vasto campo de atividades para muitos anos. Combateu, com grande denodo e perseverança, os índios pataxós, que ele denominava cutachos, os camacãs e os botocudos. Percorreu, fazendo despesas consideráveis e empregando os mais persistentes esforços, todas essas matas virgens; foi o primeiro a navegar vários rios, como o Rio Pardo, o Rio das Contas, o Rio dos Ilhéus e parte do Rio Grande de Belmonte descobrindo-lhes a embocadura no mar e as suas comunicações entre si. No Rio Pardo, sustentou vários combates contra os botocudos. Tais feitos lhe deram 
frequentes oportunidades de demonstrar um caráter extremamente decidido e grande perseverança de ânimo. Mais tarde começou a civilizar e batizar muitos camacãs; depois utilizou-se vantajosamente deles em suas incursões contra outros selvagens. Assegurou-me que os índios, reunidos aos brancos, demonstram sempre grande coragem nos combates (MAXIMILIANO, WIED-NEUWIED, 1815-1817 p. 410).

Vale destacar que o processo de ocupação territorial no Sertão da Ressaca e toda a Bahia foram realizados imersos em resistências dos povos nativos, que em diversos pontos do Território do Sertão da Ressaca, entraram em conflito armado. Evidenciandose assim, que o projeto de ocupação foi construído nos limites da oposição da própria vivência territorial dos nativos.

Percebe-se com isso que a política de ampliação do território implantada pela Coroa Portuguesa, proporcionou diversos confrontos no contexto cultural, social e territorial, em contrapartida, foram elaborados planos de controle legislativo para tentar solucionar as contradições emanadas desse processo de ocupação territorial no interior da Bahia e em todas as partes da Colônia.

Toda essa ocupação territorial pode ser confirmada em uma documentação original de 1817, escrita pelo Príncipe Maximiliano de Wied Neuwied que percorreu o trajeto entre Ilhéus e a divisa de Bahia com Minas Gerais. Em sua trajetória por este território Maximiliano (1817), observou toda a natureza e os aspectos socioespaciais existentes naquele período. Com base em suas anotações, foi possível elaborar um mapa demonstrando as principais ocupações territoriais existentes no inicio do século XIX e toda a extensão territorial comandada por João Gonçalves da Costa e, por conseguinte, transferida para os domínios econômicos e políticos de Vitória da Conquista. (ver mapa $3)$.

Maximiliano Wied-Neuwied (1817), além de abordar toda a relação sociedade/natureza existente aqui na Bahia no inicio do século XIX, garantiu uma fonte primorosa sobre o contexto espaço-tempo de Vitória da Conquista, na medida em que descreveu não somente os aspectos naturais das paisagens que ainda hoje pode ser comparada, mas também, mapeou e demarcou no território os primórdios da espacialização de cada uma das principais cidades da Bahia nos dias atuais. Com isso, hoje é possível ter uma noção dessa espacialização e toda a sua formação territorial, mediante o mapeamento de seu percurso em 1817 pelo interior da Bahia denominado naquela época de Sertão da Ressaca. (ver mapa 3). 


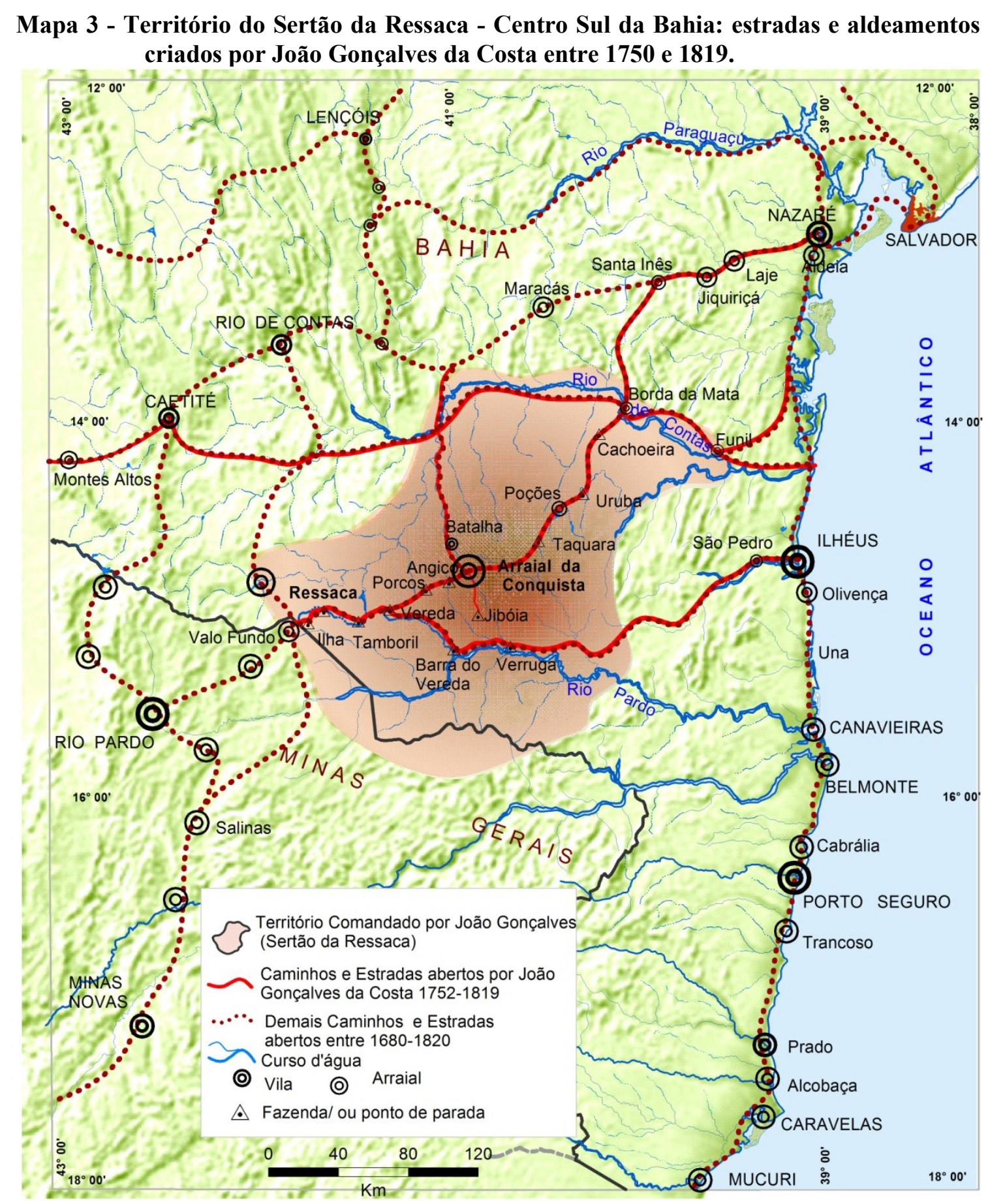

Fonte: Elaborado pelo autor com base em informações documentais do Arquivo Historico ultramarino Biblioteca Nacional - Brasil (2013) e do livro Viagem ao Brasil de Maximiliano - 1817 (1940), e do Atlas Geografico de Vitória da Conquista (2015)

É importante destacar que processo de ocupação do território no Brasil Colônia fazia parte de projeto maior dos Portugueses, com objetivos, que consistia na acumulação primitiva de capital ancorado na expansão comercial e na ampliação cada vez maior dos lucros alcançados pela utilização do trabalho escravo. 


\section{A consolidação da ocupação territorial no Centro-Sul da Bahia e as geoestratégias da produção do espaço no Sertão baiano.}

O processo de colonização da América Portuguesa e da Bahia não significou somente a anexação de novos territórios ao domínio português, mas também um processo geoestratégico, cuja ação política estava centrada na conquista das terras propriamente dita, na exploração dos habitantes locais e no tráfico de escravos.

Para a consolidação dessas geoestratégias o governo Português contou com pessoas que estavam dispostas a cumprir suas metas, aplicando uma legislação cujo comando central, era baseado numa hierarquia exterior e metropolitana. Ou seja, a centralização do poder na Europa e de lá partiam as decisões mais abrangentes para com o território, sobretudo na tentativa de encontrar novas áreas de exploração dos recursos naturais, aliados à política de fixação territorial por parte do Governo Português.

No interior da Colônia, principalmente o interior da Bahia, havia uma população mesclada e, ao mesmo tempo ilhada no território, que aos poucos iam constituindo culturas diversas, sob uma mesma base territorial, "com ilhas de desenvolvimento" (SANTOS 2004), devido à grande extensão territorial e a falta de caminhos que interligassem os diversos pontos ocupados, mas não somente isso; há que considerar também o desenvolvimento técnico científico daquele período, bem como os meios de comunicação e transporte entre os diversos pontos do território.

Quanto à continuidade das terras, deve-se levar em consideração, que ela é remanescente da Vila de Santo Antônio da Jacobina, criada em 1720, pelo Governo Geral, cuja função era de administrar e ter controle jurídico sobre toda a extensão de terras entre o sertão da margem direita do Rio São Francisco, o litoral sul baiano e sua fronteira com Minas Gerais; cuja dimensão territorial era maior que a Espanha.

Dessa comarca, surgiu em 1724, a Vila do Sacramento das Minas do Rio de Contas, cuja dimensão territorial estava em torno de $100.000 \mathrm{~km}^{2}$. Ao Sul, surgiu a comarca de Minas Novas que comandava toda a extensão de terras entre o São Francisco, e o Rio Pardo; entre Minas Novas e Rio das Contas, vários pontos de apoio foram aparecendo ao longo do século XVIII, como por exemplo, o Valo Fundo, um entreposto de alfândega e de demarcação de território entre Minas Gerais e Bahia.

Nesse fracionamento a Vila do Rio de Contas passa então a comandar toda essa porção territorial, inclusive as terras pertencentes ao Arraial de Sant'anna do Caetité (1730) e do Arraial da Conquista (1750). 
Por volta de 1810, ocorre o desmembramento da Vila Nova do Príncipe e Santana do Caetité, com uma extensão territorial de cerca de $52.000 \mathrm{~km}^{2}$. Em 1840, desmembra-se o arraial da Conquista, que passa a ter o status de Villa. Assim o município da Conquista abrange vastas terras que hoje configuram as Cidades de Poções, Boa Nova, Planalto, Belo Campo, Anagé, Candido Sales, Encruzilhada, Itambé, Itapetinga, Caatiba, Barra do Choça, entre outros.

Um destaque importante deve ser dado para a ocupação das terras que hoje compõe o município de Poções já que a Familia dos Gonçalves da Costa, tiveram seus últimos dias de vida nas propriedades que circundavam o arraial de poções no inicio do século XIX. As primeiras povoações ocorreram as margens do Rio São José no atual centro urbano da cidade de Poções.

O processo de territorialização que deu origem as primeiras edificações do núcleo urbano inicial ocorre com a distribuição das terras recém-ocupadas pelo Português João Gonçalves da Costa para os principais membros da família Gonçalves da Costa, terras conhecidas como Morrinhos, Uruba e Cachoeira. Essas propriedades localizadas nos arredores da primeira nucleação urbana de Poções passaram a compor o principal elo entre o então centro consumidor recém-estabelecido e as áreas produtivas dessas fazendas

\section{Considerações finais}

O ritmo da expansão territorial que configurou a produção do espaço no Centro Sul da Bahia, mais especificamente no Sertão da Ressaca, foi determinado pela lógica da apropriação das terras e no arranjo socioespacial das vilas e aldeamentos ocorridos nesse período.

Esse ritmo de crescimento principalmente das localidades do entorno da Capital do Sertão da Ressaca que neste caso era o Arraial da Conquista, atual Vitória da Conquista, foi moldado pela condição econômica dos habitantes da época, tidos como a elite coronelista que se resumia às famílias do Capitão mor Antônio Dias de Miranda e seus descendentes, as famílias do agora já Coronel João Gonçalves da Costa e seus descendentes, além de alguns outros comerciantes, tropeiros, vaqueiros, ferreiros e artesãos que por aqui aportaram. Isso por que durante muito tempo por mais de dois séculos (séc. XVIII e XIX), a atividade econômica que prevalecia nas terras pertencentes a atual Vitória da Conquista era a pecuária extensiva que não necessitava 
de grande quantidade de mão de obra, mesmo tendo à disposição na época mão de obra escrava, e indígena para realizar tarefas, a vasta região não era tão densamente povoada.

Outro fato importante é que em cada propriedade da família do Coronel João Gonçalves da Costa no final do Seculo XVIII, havia pelo menos uma dúzia de escravos negros e mais uma dezena de índios ou descendentes diretos de Camacãs que desmatava, plantava e colhia algodão, milho e feijão. Como eram dezenas de propriedades já demarcadas constata-se que esse contingente populacional que habitava tais propriedades gerou uma população cada vez mais numerosa com o passar dos tempos, propiciando mais tarde no final do século XIX, novos aldeamentos, quilombos e ou povoados que hoje configuram pequenos municípios vilas do Centro Sul da Bahia.

\section{Referências}

ARQUIVO HISTÓRICO ULTRAMARINO. Inventário dos documentos relativos ao Brasil existente nos arquivos do Conselho Ultramarino de Lisboa, vol. 1-8. Rio de Janeiro: Biblioteca Nacional-BN, 1936.

ARAÚJO, J.J. A. Edital do ouvidor geral e Corregedor de Jacobina, sobre a jurisdição na parte do Rio Pardo entre Bahia e Minas Gerais de 26 de junho de 1766 . IN:

Inventário dos documentos relativos ao Brasil existente nos arquivos do Conselho Ultramarino de Lisboa, códice 7457, 1766. . Rio de Janeiro: Biblioteca Nacional-Ba, acessado em março de 2012.

BRASIL. BIBLIOTECA NACIONAL. ANAIS: Inventário dos documentos relativos ao Brasil, existente no Arquivo da Marinha e Ultramar de Lisboa vol. 1 a 72. Rio de Janeiro. BN, acessado em março de 2012.

BOCARRO\&CASTANHEDA, J. I. de B.; CORREA, A.; LOBO, J.C. Oficio dos

Governadores interinos da Bahia, para Martinho de Melo e Castro sobre a Capitania da Bahia e da Comarca de Ilhéus, 23 de agosto de 1783. Códice, 11.314 IN: Inventário dos documentos relativos ao Brasil existente nos arquivos do Conselho Ultramarino de Lisboa, Rio de Janeiro: Biblioteca Nacional-BN, acessado em março de 2012.

BRITO, J. de S. da G. de M. e T. G. de. Oficio do Governador da Bahia, Conde da Ponte para o Visconde de Anadia, sobre a exploração das margens do Rio Pardo, pelo Capitão mor João Gonçalves da Costa- Bahia, 31 de maio de 1807. Códice, 29.878 IN: Inventário dos documentos relativos ao Brasil existente nos arquivos do Conselho Ultramarino de Lisboa, Rio de Janeiro: Biblioteca Nacional-BN, acessado em março de 2012.

CARLOS, Ana Fani Alessandri. Da "organização" à " produção" do espaço no movimento do pensamento geográfico. In: CARLOS, Ana Fani Alessandri et. al. A produção do espaço urbano: agentes e processos, escalas e desafios, São Paulo: Contexto, 2011. 
CARLOS, A. F. A. A condição espacial. São Paulo: Contexto, 2011.

COSTA, J. G. Memória sumária e compendiosa da conquista do Rio Pardo, pelo Capitão mor João Gonçalves da Costa- Bahia, 1806-1807. Códice, 29.878 IN:

Inventário dos documentos relativos ao Brasil existente nos arquivos do Conselho Ultramarino de Lisboa, Rio de Janeiro: Biblioteca Nacional-BN, acessado em março de 2012.

LEFEBVRE, H. La producción del espacio. Madri: Capitán swing, 2013, 468 p.

MAXIMILIANO, P de W. N. Viagem ao Brasil. São Paulo: Companhia Ed. Nacional, 1940.

MAXIMILIANO, P. de W. N. Viagem ao Brasil 1815-1817. São Paulo:

Melhoramentos, 1969.

MENEZES, V. F. C. de. Carta ao Rei de Portugal João V, em 15 de março de 1728, sobre a conquista do Gentio "bárbaro" no "Certão" do Rio das Contas, Rio Verde. Cabeceiras do Rio São Matheus e do Rio Pardo. IN: inventário dos documentos relativos ao Brasil existentes no arquivo de Marinha e ultramar de Lisboa. Rio de Janeiro: Biblioteca Nacional-Ba, 2012.

MENEZES, M. da C. Oficio para Martinho de Mello e Castro sobre a Capitania de Ilhéus, Lisboa, 12 de agosto de 1780 . IN: Inventário dos documentos relativos ao Brasil existente nos arquivos do Conselho Ultramarino de Lisboa, códice 10653, Rio de Janeiro: Biblioteca Nacional-BN, acessado em março de 2012.

NEVES, E. F. Escravidão, pecuária e policultura: Alto Sertão da Bahia, século XIX. Feira de Santana: UEFS Editora, 2012. 305 p.

ROCHA, A. A.; FERRAZ, A. E. de Q. Atlas geográfico de Vitória da Conquista. Vitória da Conquista: Edição dos Autores, 2015

ROCHA, A. A.. A identidade territorial de vitória da conquista em seu processo de formação socioespacial e urbanização. Anais Colóquio Baiano: tempos, espaços e Representações: Abordagens geográficas e históricas. Vitória da Conquista, UESB, 2013. disponível em:

http://periodicos.uesb.br/index.php/coloquiobaiano/article/viewFile/2857/pdf_84

.Sociedade \& Natureza: A produção do espaço urbano em bacias

hidrográficas, Vitória da Conquista, Edições UESB, 2011.

SANTOS, M. Metamorfoses do Espaço habitado. 6a ed. São Paulo: Edusp, 2008.

SANTOS, M.. O Retorno do Território. In: SANTOS, Milton; SOUZA, Maria Adélia A.; SILVEIRA, María Laura (Orgs.). Território: Globalização e Fragmentação. São Paulo:Hucitec/Anpur, 2006

SANTOS, M. A natureza do espaço: técnica e tempo razão e emoção. São Paulo: EDUSP, 2004.

SILVEIRA, M.L. O Brasil: território e sociedade no início do século 21 - a história de um livro, Acta Geográfica, Edição Especial, Boa Vista- UFPR, 2011.

VALENÇA, M. de. Carta patente pela qual o Governador Marquez de Valença nomeou João Gonçalves da Costa a Capitão mor da Conquista do sertão da Ressaca - Bahia, 31 
de julho de 1781. Códice 21.725. IN: Inventário dos documentos relativos ao Brasil existente nos arquivos do Conselho Ultramarino de Lisboa, Rio de Janeiro:

Biblioteca Nacional-BN, acessado em março de 2012. 